Taylor heeft zich niet met de verkoop bezig gehouden; Ford natuurlijk wel.

Ford heeft ook tegenslag gekend en depressies doorgemaakt. Er is ook genoeg over zijn fabrieken en methodes bekend geworden, dat laat zien dat alles daar niet altijd perfect was ingericht, dat er veel humbug stak in zijn publicaties, en dat zijn houding en methodes van behandeling van anderen niet altijd bewonderenswaardig uitvielen.

Ford heeft als de man van de rationele standaardisatie in de praktijk laten zien wat er mogelijk is, en in dit opzicht spreekt hij sterk tot de verbeelding van het grote publiek. En het is wel zeker dat de economische verschuivingen van de laatste jaren wel zullen dwingen hem te volgen.

\title{
BALANSPROBLEMEN IN VERBAND MET DE NIEUWE INVES- TERINGEN
}

door Drs. A. M. Groot.

De bedrijfsomstandigheden, waaronder de productiemiddelenindustrie op het ogenblik werkt zijn wel verre van normaal. De achterstand in scholing en opleiding van personeel heeft geleid tot een ernstig tekort aan vakarbeiders, de algemene personeelschaarste noodzaakt er toe mensen in het bedrijf op te nemen, die niet beschikken over de vereiste capaciteiten; veelal moeten deze arbeiders met de daaraan verbonden hoge kosten van heinde en ver worden gehaald. Voegt men daaraan dan nog toe, dat de algemene productiviteit van de geschoolde arbeiders beneden het normale ligt, dan zijn dat argumenten genoeg, die verklaren, dat de arbeidskosten per eenheid abnormaal hoog zijn.

Ten aanzien van de kosten van de productiemiddelen, die in deze bedrijven gebruikt worden, geldt geheel hetzelfde. De productie-installatie is verouderd, belangrijke en nagenoeg onmisbare machines zijn weggevoerd en ook wat de productiemiddelen betreft beschikt dus de industrie thans niet over de meest economische outillage. Ook de kosten der productiemiddelen per eenheid product zijn dus ver boven normaal.

Ten aanzien van de grondstoffen zijn de omstandigheden thans nog meer afwijkend van het normale. De normale grondstoffenproducenten zijn voor een groot deel uitgeschakeld. Het voor de productie nodige hout, ijzer en staal moet een reis om de halve wereld maken, voordat het de verwerkende industrie heeft bereikt. De onregelmatige toevoer van grondstoffen, de talrijke storingen in de productie, de talrijke overheidsmaatregelen op elk gebied voeren de indirecte kosten in sterke mate op.

Het vorenstaande moge voldoende zijn om aan te toonen, dat de prijzen die thans voor de aanschaffing van nieuwe productiemiddelen gelden abnormaal hoog zijn. Daarbij doet de ongelukkige omstandigheid zich voor, dat juist thans door de achterstand in de vervanging, de oorlogsschade en de Duitsche roof, op korte termijn belangrijke nieuwe investeringen noodzakelijk zijn. Indien de waarde van het geld onveranderd zal blijven, mogen wij dan ook wel aannemen, dat de prijzen die thans betaald worden voor de nieuwe productiemiddelen hoger zijn. dan die welke in de toekomst zullen gelden en daarin schuilt voor de betrokken bedrijven een ernstig gevaar, n.l. het gevaar van kapitaalverwatering. De balans, die thans wordt gevoerd moet er op gericht zijn dat gevaar voor de toekomst af te wenden.

In een periode, waarin vervanging en afschrijving met elkaar in evenwicht zijn, wordt bij de toepassing van de vervangingswaardetheorie bij de berekening van de afschrijvingen, de invloed van de prijsfluctuaties

m a b blz. 166 
bij nieuwe investeringen gecompenseerd. Indien alle aanwezige activa gewaardeerd worden, onafhankelijk van het jaar van aanschaffing, op basis van het prijsniveau op een bepaald tijdstip (standaardwaarde), dan kan jaarlijks het bedrag der afschrijvingskosten als volgt worden berekend. De afschrijvingen worden berekend in een vast percentage van de standaardwaarde, jaarlijks wordt een indexcijfer vastgesteld, dat aangeeft de verhouding tussen het prijspeil van het basisjaar en het prijspeil van het betrokken jaar. De over de standaardwaarde berekende afschrijvingen worden jaarlijks op grond van dat indexcijfer gecorrigeerd voor de berekening van de afschrijvingskosten op basis van vervangingswaarde. Zijn dus de afschrijvingen over de standaardwaarde $f 100.000$. - en is het indexcijfer 140, dan zijn de afschrijvingen op basis van vervangingswaarde

140

$100 \times f 100.000 .-=f 140.000 .-$.

Van dit bedrag komt $f$ 100.000. - ten gunste van de afschrijvings rekening, de resteerende $f 40.000$. - wordt gestort in een fonds voor nivellering van prijsverschillen op nieuwe investeringen. Als nu in het betr. jaar de afschrijvingen in overeenstemming zijn met de investeringen en dus op basis van het prijspeil van het basisjaar $f$ 100.000. - bedragen dan zijn de werkelijke investeringen $140 \%$ van $f(100.000 .-=$ $f$ 140.000. - en het verschil tussen de standaardwaarde, die in de balans wordt opgevoerd en de werkelijke investering kan dus juist worden gedekt uit de toeslag ad $f$ 40.000. - die op de afschrijvingen wordt gelegd om deze te baseren op de vervangingswaarde. Zolang dus de investeringen enigszins gelijkmatig over de jaren verdeeld zijn en geen expansie plaats vindt, kunnen positieve en negatieve prijsfluctuaties op nieuwe investeringen gedekt worden uit het verschil tussen afschrijvingen op standaardwaarde en afschrijvingen op vervangingswaardebasis. De balanswaardering kan dus steeds gehandhaafd worden op de standaardwaarde.

Zooals hiervoren echter reeds werd opgemerkt zijn de evenwichtsvoorwaarden voor deze theorie (gelijkheid vervanging en afschrijving) thans ernstig verstoord en de bedrijven, die de bedoelde methode hebben gevolgd, beschikken thans over een belangrijke reserve van niet in nieuwe investeringen verwerkte toeslagen op de standaardafschrijvingen, deze reserve is echter gedevalueerd, omdat het prijsniveau een steeds voortgaande stijging vertoont. Zelfs indien de huidige prijzen der productiemiddelen niet onder abnormale invloeden zouden staan zou daardoor een correctie op deze reserves noodig zijn. Nemen wij aan dat het verloop der indexcijfers was:

$\begin{array}{ll}1943 & 140 \\ 1944 & 160 \\ 1945 & 170 \\ 1946 & 190 \\ 1947 & 200\end{array}$

dan zou men op het onverwerkte deel van de reserve ' 43 een toeslag van $60 / 140$ op het onverwerkte deel van 1944 van $40 / 160 \mathrm{enz}$. moeten bijreserveren. Deze extra-reserve zou gevormd moeten worden uit de winst, want deze noodzakelijke dotaties zijn natuurlijk geen kosten van de huidige productie, alternatief zou de mogelijkheid openstaan deze toevoeging aan deze reserve te dekken door een herwaardering der activa, indien men veronderstelt dat het toekomstige prijsniveau der productiemiddelen duurzaam zal liggen boven de aangenomen standaardwaarde, 
die gewoonlijk op het voor-oorlogsche prijsniveau zal zijn gebaseerd. Dit is dus een eerste correctie, die noodzakelijk is, maar zij is op zichzelf niet voldoende, want zooals hiervoren reeds werd aangetoond wordt de prijsvorming in de productiemiddelenindustrie thans wel degelijk door zeer abnormale factoren beïnvloed. Dat stelt de vraag aan de orde of strikte toepassing van de methode om de afschrijvingen te corrigeren op basis van het indexcijfer, zooals hiervoren aangegeven, thans wel te verdedigen is en volgens mijn mening is dat niet het geval.

Uit enkele onderzoekingen, die door mij zijn ingesteld, blijkt dat voor bepaalde productiemiddelen die ten opzichte van het voor-oorlogse prijsniveau een indexcijfer van 435 á 450 hebben bereikt, het indexcijfer slechts 240 à 250 zou zijn, bij terugkeer van normale arbeidsproductiviteit, normale bedrijfsoutillage en normale grondstoffenvoorziening. Er dringen zich nu twee vragen op n.l.

a. moeten de in de oorlog niet door nieuwe investeringen verwerkte verschillen tussen standaardafschrijving en afschrijving op vervangingswaardebasis nu tot het niveau 250 of tot het niveau 450 gecorrigeerd worden.

b. moet men bij de huidige herleiding der afschrijvingen tot de vervangswaarde het indexcijfer 250 of 450 gebruiken.

Het is mijn persoonlijke overtuiging, dat in beide gevallen het percentage 250 en niet 450 toepassing moet vinden, doch ik acht het van groot belang deze mening eens te toetsen aan die van andere deskundigen. Overzien wij eerst wat de consequenties van dat standpunt zijn, dan blijkt, dat van alle nieuwe investeringen direct bij aanschaffing 200/450 als verlies geboekt zou moeten worden om een toekomstige overkapitalisatie te voorkomen. Dit is een zeer ernstige consequentie, want bij de belangrijke investeringen die in deze jaren plaats vinden, legt dit een enorme extra last op de verlies- en winstrekening. Daar komt nog bij, dat de fiscus deze methode zeker niet zal aanvaarden voor de vaststelling van de fiscale winst, zoodat dit verlies gedekt moet worden uit hetgeen de fiscus aan het bedrijf als winst beschikbaar laat, nadat zij haar aandeel daarin heeft opgevorderd. Indien deze reserve daartoe voldoende is kan dit verlies natuurlijk ook gedekt worden tit een herwaarderingsreserve die zal ontstaan als de thans aangenomen standaardwaarde wordt verhoogd tot het voor de toekomst te verwachten prijspeil.

De motieven die er naar mijn mening toe moeten leiden bij de beantwoording der beide hiervoren gestelde vragen genoemde abnormale omstandigheden te elimineren zijn de volgende:

1. de waarde van de vootraad productiemiddelen, welke de grondslag vormt voor de vaststelling van de afschrijvingskosten, wordt alleen dan bepaald door de prijs die men voor de toegevoegde eenheden moet betalen, als de nieuwe productiemiddelen onder normale omstandigheden en in vrij ruilverkeer kunnen worden voortgebracht.

2. indien het productieapparaat in de achter ons liggende jaren in tact gebleven zou zijn en ook regeimatig vernieuwd zou zijn, zou bij de thans geldende abnormale prijzen voor de productiemiddelen de ververvanging enige jaren geheel opgeschort worden.

$B_{i j}$ de samenstelling van de balans over $1946 \mathrm{zal}$ men reeds in vele bedrijven voor de moeilijke keuze gesteld worden in deze kwestie een principieel standpunt te kiezen en het over 1946 becijferde resultaat zal sterk afhankelijk zijn van de beslissing die te dien aanzien genomen wordt. De "dure" investeringen van de vorige oorlog hebben vele bedrijven, die het principe van afschrijving over de aanschaffingswaarde volgden tientallen van jaren in een noodlijdende positie gebracht. De

m a b blz. 168 
crisisverschijnselen zijn daardoor in de jaren na 1921 belangrijk verscherpt

Het ware te wensen, dat fiscale maatregelen zouden worden getroffen, die het voeren van een conservatief balansbeleid in dit opzicht zouden bevorderen, doch dat is onder de huidige omstandigheden op zijn minst genomen zeer twijfelachtig.

Naschrift.

De schrijver van bovenstaande beschouwing stelt een uitermate belangrijk vraagstuk aan de orde, dat de aandacht van het bedrijfsleven in het bijzonder van de accountants verdient. De Redactie zal gaarne plaatsing verlenen aan bijdragen over dit onderwerp.

REDACTIE.

\title{
TAAK EN VERANTWOORDELIJKHEID VAN DE ACCOUNTANT IN DE GELEIDE ECONOMIE
}

\author{
door A.J. A. Vos
}

Het na-oorlogse bedrijfsleven bereidt er zich, al of niet con amore. op voor dat het in de toekomst haar bedrijfspolitiek niet meer alleen zal hebben te richten naar de verhoudingen op de afzetmarkten, zich weerspiegelend in de te behalen prijzen, doch dat de Overheid in meerdere of mindere mate regelend zal optreden.

De toonaangevende politieke groeperingen, die heden ten dage in $\mathrm{Ne}$ derland en in de meeste Westeuropese landen de regeringspolitiek bepalen of in sterke mate beïnvloeden, staan in beginsel een geleide economie voor. Onder geleide economie wordt dan verstaan een dusdanige organisatie van het economisch proces dat de ondernemer weliswaar zijn zelfstandigheid behoudt, doch zich in zijn productieplannen moet richten naar de directieven, die hogere organen zullen vaststellen. Het spreekt daarbij vanzelf dat die directieven zeer verschillend, zowel wat hun aard als hun reikwijdte betreft, in de gang van zaken bij de individuele onderneming kunnen ingrijpen. Hierop in te gaan ligt echter buiten het kader van dit artikel.

De hogere organen, ingesteld door de Overheid en samengesteld uit deskundigen en bedrijfsgenoten, zullen bij het treffen van hun maatregelen zich moeten afvragen, welke gevolgen deze zullen hebben. De problemen, die zich hierbij voordoen, zijn zowel van algemeen economische als van bedrijfseconomische aard. Het vaststellen van een prijs b.v. houdt in een bepalen van een kostencalculatie voor de betrokken bedrijfstak en schept dus bedrijfseconomische problemen; tevens echter kan het inhouden, dat het betrokken product een plaats krijgt aangewezen in de scala van de veronderstelde maatschappelijke behoefte: de problemen, die hierbij onder het oog moeten worden gezien, zijn van algemeen economische aard.

Het bedrijfsleven zal aan de Overheid, vertegenwoordigd door de vorenbedoelde hogere organen, de gegevens moeten verschaffen, waarop haar oordeel kan worden gebaseerd omtrent de wenselijkheid en de gevolgen van de te nemen maatregelen. De Overheid zal middelen moeten vinden, deze gegevens op hun objectieve juistheid te toetsen en de getroffen maatregelen op hun richtige uitvoering zowel als op hun uitwerking te doen nagaan.

De accountant, vertrouwensman van het maatschappelijk verkeer, deskundige op het gebied der bedrijfseconomie, ziet zich voor de vraag 